\title{
4.2 Roman Africa and Class Identity
}

Although Roman scholars have for some time discussed Roman "classes," such as senatorial, equestrian, etc., fewer have applied class theory from Anthropology or other academic disciplines. ${ }^{21}$ Noting the attitude of many classicists, David Konstan comments, "By and large, classical scholars have tended to claim for Greek and Roman literature a superiority to mundane economic and political concerns, and to treat it as a storehouse of timeless values and transhistorical or metaphysical meaning that pertain not to collective entities such as class but to problems in the lives of autonomous individuals." ${ }^{22}$ Facing such presuppositions, P.W. Rose answers, "In Homer, despite objections to 'class conflict' analysis, 'conflict' seems to me the only accurate term to describe the class relationships of central interest in the Odyssey." 23 Most discussions of Roman class either follow the traditional approach, with class constructed legally, or alternative and complementary models, which view class identity as constructed ideologically.

Roman class systems consisted of various divisions of society, often enacted into Roman law. Because of elite bias in the sources, most discussions treat only the class identity of the upper levels of society, as Gruen laments, "Ancient writers, notoriously, were unconcerned with the behavior and feelings of the lower orders. Their focus was politics and war. Social questions, economic distress, a struggle between classes that may have lain beneath the surface were items not considered worthy of serious attention." 24 Roman classes are typically outlined, therefore, in terms of senatorial, equestrian and lower classes, or more generally with an honestiores/humiliores dichotomy. ${ }^{25}$

Moreover, the phenomenon of citizenship bestowal became extremely important, especially because only citizens could attain higher office, vote and receive all of the benefits of the empire. As the body of "citizens" increased, especially during the later empire, citizenship became a less important distinction for identity, and many of the merchants throughout the region of the empire prospered from the empire's conquests to the extent that they attained a higher status than many citizens. Citizenship also began to blur the classic

21 Two examples are Gruen, "Class Conflict and the Third Macedonian War," AJAH 1 (1976): 29-60; and R.J.A. Talbert, "The Role of the Helots in the Class Struggle at Sparta," Historia 38 (1989): 22-40. For an overview of class in ancient societies such as Greece and Rome by class theorists, see P. Calvert, The Concept of Class, (London: Hutchinson, 1982), 12-44; and a brief discussion of class in the Roman Empire by Edgel, Class, 1. For anthropological theories of class applied to archaeology, see Meskell, "The Intersection."

22 "The Classics and Class Conflict," Arethusa 27 (1 1994), 48.

23 "Class Ambivalence in the Odyssey" Historia 24 (1975), n.1.

24 "Class Conflict," 46-7.

25 Two helpful studies on the nuances of the senatorial class are T.D. Barnes, "Who Were the Nobility of the Roman Empire?" Phoenix 28 (1974) 444-9; and Michele Renee Salzman, The Making of a Christian Aristocracy: Social and Religious Change in the Western Roman Empire, (HUP, 2002), 22. On the changes to the equestrian class over time, see J. Osier, "The Emergence of Third-Century Equestrian Military Commanders," Latomus 36 (1977): 674-687. 
Roman/barbarian distinctions, as Rives argues, "Nor did the Roman government consider all these areas within the empire as equally Roman. For an emperor like Tiberius, the scion of an ancient republican family, only the urbs Roma was truly Roman, while the rest of Italy was Roman only by extension, and Africa and the other provinces only in the sense that they were ruled by Rome." ${ }^{26}$ While certain traits were defined in legal code to establish classes, other aspects of society constructed class identity and ideology in terms of status symbols.

With the lack of sources for the lower ranks of society, historians look to the "the production of an aristocratic, ruling class ideology and its immanent tensions" with the lower ranks. ${ }^{27}$ In other words, one can explore the ways in which class identity was constructed through the symbols and values underpinning the social stratification of Roman society. A prominent status symbol that has already been mentioned in terms of kinship is the domus, which also invokes a class identity. ${ }^{28}$ Another way in which the domus constructed class identity, was by the juxtaposition with the slave "Other":

There was also an awareness, at least among some Romans, that had the vicissitudes of war been different, they themselves could have become the slaves. Under such circumstances, it is not surprising to find, in some areas of Roman culture, an almost neurotic need for the slave to be fundamentally different from the master. Moreover, it was not enough that he be a different type of person; rather, he had to be a different type of creature all together - a speaking tool, a pack animal, an appendage psychically linked to his master's will. That such patent absurdities survived despite the fact that the slave, like his master, had two arms, two legs, human feelings, and intellect is telling. But it was in fact this very shared humanity, and elite discomfort with it, that were responsible for the Roman's dehumanizing constructions of the slave. Reclassifying the slave as non-human, as "not like us," was a somewhat clumsy solution to a deeply rooted ideological conflict.

Slave-holding and the domus of course were part of the wider symbolism of wealth and power. ${ }^{30}$ Often wealth enabled a Roman's status in terms of education or office which were accessible through property and other status symbols. ${ }^{31}$ It was these status symbols that helped to construct one's identity as a Roman. As Hope states, "In short, the Roman world was a status-conscious place, where a value was put on access to and use of status symbols such as a special seat at the

26 Religion, 171.

27 Konstan, "The Classics," 48.

28 For bibliography and discussion in terms of class, see Treggiari, "The Upper-class House as Symbol and Focus of Emotion in Cicero," JRA 12 (1999): 33-56.

29 Mahalia L. Way, "Violence and the Performance of Class in Plautus' Casina," Helios 27 (2 2000), 204.

30 Konstan, "The Classics," 68.

31 Saller, "Promotion and Patronage in Equestrian Careers," JRS 70 (1980): 44-63. 
theatre or a detail of dress." ${ }^{32}$ The "Roman world" as it expanded to colonize the provinces exported the ideological importance of status and class. ${ }^{33}$

The indigenous Africans organized along different lines with most Libyan villages led by elders, and most land likely owned and worked communally. ${ }^{34}$ Clans and broader societal structures also followed the pattern of the villages. ${ }^{35}$ As Roman influence came to bear on the indigenous Africans, they were labeled as both barbaric and humiliores (humble class), a status which would have subjected them to the dual penalty system which

reserved for people of humble status capital sentences like crucifixion and damnatio ad bestias (a mauling to death by wild animals in the arena), and the harsher noncapital penalties like hard labour in the mines, flogging, and chained imprisonment. Nor were humiliores allowed to bring against their "betters" civil actions like those of fraud, theft, and grievous bodily harm, for such charges, by their very nature, would involve derogation of the respectability (honestas) of people of rank and high status and a denial of the deference (reverence) that was their due. ${ }^{36}$

While much work has been done on wealth and status in the provinces, the class identity of indigenous populations remains elusive, except for instances of new elite class identity. ${ }^{37}$

The new elite population that burgeoned under Roman colonization in North Africa attempted to transcend their class identity and move upwardly into the Roman nobility. Salzman notes, "In the western empire the senatorial aristocracy had spread its institutions, values and lifestyle so thoroughly that, by the late third

32 "Status and Identity," 150.

33 Richard Gordon, "From Republic to Principate: Priesthood, Religion and Ideology," in Roman Religion, ed. Clifford Ando, (EUP, 2003), 74-5, originally in Pagan Priests: Religion and Power in the Ancient World, ed. M. Beard and J. North, (Ithaca, NY: Cornell University Press, 1990), 179-98, claims, "This more or less uncontrolled imperialism led in turn to class, or quasi-class, formation."

34 On sources of African "elders," see Shaw, Rulers, Nomads and Christians in Roman North Africa, (Aldershot, Hampshire: VARIORUM, 1995), originally as "The Structure of the Local Society in the Early Maghrib: the Elders," The Maghreb Review 16, nos. 1-2 (1991), 18-54. For land usage, see Cherry, Frontier, 18.

35 Cherry, Frontier, 19-20; Cherry uses the term "tribe," which has been criticized by anthropologists Tonkin, McDonald, and Chapman, History and Ethnicity, 20, as a generic term applied to any "political units that are not of the familiar nation and nation-state kind." cf. discussions in Atkinson, Roots of Ethnicity, 12-3; and Eriksen, Ethnicity and Nationalism, 9-10.

36 Lloyd J. Thompson, Romans and Blacks, (London: Routledge Press, 1989), 145.

37 For wealth in Britain, see N.B. Aitchison, "Roman Wealth, Native Ritual: Coin Hoards within and beyond Roman Britain," WA 20 (2 1988): 270-284; for Egypt, see Haas, Alexandria, 51; for Gaul, see J.F. Drinkwater, "Gallic Personal Wealth," Chiron 9 (1979): 237-242, and response by R.P. Duncan-Jones, "The Wealth of Gaul," Chiron 11 (1981): 217-220; for Greece, see Vincent J. Rosivach, "Class Matters in the Dyskolos of Menander," CQ 51 ( 1 2001): 127-134; for Italy, see N. Purcell, "Wine and Wealth in Ancient Italy," JRS 75 (1985): 1-19; for Spain, see L.A. Churchin, "Personal Wealth in Roman Spain," Historia 32 (1983): 227-244. 
century, aristocrats from Spain and Africa can be said to have lived very similar lives and to have held many of the same values." 38 The shared "values" and ideals marked the new elites in North Africa, those individuals who accommodated a sense of romanitas in terms of a class identity. Early in the period of colonization, the freedmen, a position representing upward mobility, were given positions of authority in their homeland. ${ }^{39}$ Later into the Roman Empire, more and more Africans rose in the social ranks of the colonizers.

The North African writer, Fronto, claimed to have transcended his indigenous African status of "barbarian." and moved to Rome, wherein he interacted with the most prestigious circles of society. ${ }^{41}$ Champlin observed, "Thus Fronto and his brother, Quadratus, should be seen not as isolated phenomena but as products of the process of Romanization which was leading the African aristocracy to its destined role in the Roman senate in the late first and early second centuries, after a proper period of training in the equestrian class., ${ }^{, 2}$ The primary factors of wealth and education played a role in aiding the new elites to move up through Roman social structures.

To be admitted into the noble classes one needed wealth, and Africa under Rome grew wealthy. This phenomena was widespread, as Raven states, "Many Africans were now rich enough to be admitted to the Roman knights class; there were perhaps three or four equestrian families in the average sized African city, and members of these families could make careers for themselves in the imperial administration or as officers in the army." ${ }^{, 43}$ It is plausible that the empire did not necessarily entice many Africans to become Romans but rather to seek after Roman extravagancies, as Cherry reasons, "In fact, it could be argued that there was little about Roman culture that was inherently desirable, perhaps only, in MacMullen's estimation, 'hot baths, central heating, softer beds, and the pleasures of wine." ${ }^{, 44}$ Wealth provided many indigenous Africans with the resources to enter into the Roman social classes, and thereby become the new elite of North Africa. Returning to the example of Apuleius, sources indicate that he attained

38 The Making, 19-20.

39 Broughton, Romanization, 55.

40 See Epistula ad M. Caesarem 5, "I will compare myself, then, with Anacharsis, not, by heaven, in wisdom, but as being like him a barbarian. For he was a Scythian of the nomad Scythians,

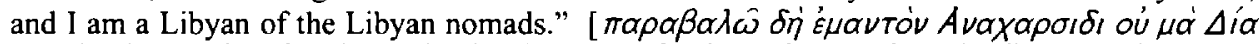

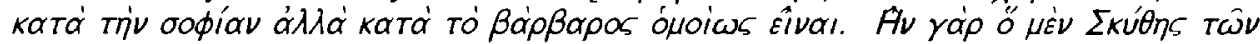

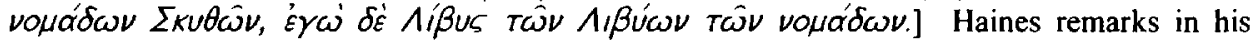
introduction to the $L C L$ edition (xxiii) that Fronto "jestingly calls himself" a Libyan, and Haines deduces from Fronto's name that "he was doubtless a Roman citizen," as if the two were mutually exclusive.

41 On the importance of education for the new elite in general, and for Fronto in particular, see Miles, "Communicating Culture, Identity and Power," in Experiencing, ed. Huskinson, 48-9.

42 Fronto, 10

43 Raven, Rome, 126.

44 Frontier, 81; ref. R. MacMullen, Changes in the Roman Empire: Essays in the Ordinary, (PUP, 1990), 63. 
enough wealth to traverse class boundaries. When the orator defended himself against the charge of greed, he pointed out that he had inherited two million sesterces, but with it, he brags, "I have lent support to most of my friends, I have shown my thanks to many of my teachers, and some of their daughters I have even provided with a dowry. For I would not have hesitated to spend my entire patrimony on what is worth more, through contempt of it." ${ }^{45}$ With this wealth, as Augustine tells,

[Apuleius] was so ambitious of greatness that he gave spectacles of gladiatorial combats, provided the dresses of those who fought with wild beasts in the circus and, in order to get a statue of himself erected in the town of Coea, the birthplace of his wife, appealed to law against the opposition made by some of the citizens to the proposal, and then, to prevent this from being forgotten by posterity, published the speech delivered by him on that occasion. ${ }^{46}$

Wealth allowed the indigenous Africans to acculturate in the social spheres of the Roman colonizers, thus placing them in two spheres of identity.

The other major factor that allowed the new elite to be upwardly mobile was education in that education allowed one to travel abroad and to become "civilized." Apuleius likely began his study in his hometown of Madauros, before going on to Carthage to learn rhetoric, and later travelling to and studying in Athens, the center of higher learning in his day. ${ }^{47}$ Stephen J. Harrison emphasizes the importance of Apuleius' education, by stating, "His life falls at the height of the Greek intellectual revival of the Second Sophistic, when Greek writers famously sought to revive the past glories of their culture in the rich cities of the Greek Mediterranean under the protection of Roman rule. Apuleius' choice of career and literary genre are fundamentally influenced by what was happening to his contemporaries in the Greek world." 48 The two factors of wealth and education empowered many Africans dissociate their previous class identity and appropriate that of upper class Romans.

The consideration of class identity in North Africa illustrates some of the ways ancients constructed their identity in the midst of a postcolonial context. By

45 Apologia 23: Nam et amicorum plerisque opem tuli et magistris plurimis gratiam rettuli, quorundam etiam filias dote auxi; neque enim dubitassem equidem uel uniuersum patrimonium impendere, ut acquirerem mihi quod maius est contemptu patrimonii.

46 Epistula 138.19: pro magno fuit ut munera ederet, uenatoresque illos uidelicet qui sese in iis exercebant muneribus, quae Apuleius exhibebat. Munera quippe dicebantur ludi non modo gladiatorum, sed etiam uenatorum, id est in bestias pugnantium. Venationes, quae munera uocantur, saturno attributae sunt. Vestiret, et pro statua sibi apud Coenses locanda, ex qua ciuitate habebat uxorem, aduersus contradictionem quorumdam ciuium litigaret? quod posteros ne lateret, eiusdem litis orationem scriptam memoriae commendauit. (This quote includes the variant readings on which Cunningham's translation relies.)

47 Hilton, "Introduction by John Hilton to Florida," in Apuleius: Rhetorical Works. ed. Stephen J. Harrison, (OUP, 2001), 126.

48 "General Introduction: Life and Writings of Apuleius," in Apuleius, ed. Harrison, 2. 
applying class theory, historians can explain some of the reasons why individuals could belong to two distinct social identities, Roman and African. Class theory also helps to explain why some indigenous A fricans could and did construct for themselves a Roman identity and others did not.

\subsection{Ancient African Christians and Class Identity}

Scholarly debate regarding the issue of class in early Christianity is by no means new. Peter Brown summarizes the exasperation of many recent historians when he says, "There is little room for the myth ...which presents the advance of Christianity as due to the spread of a religion of mercy and equality among the underprivileged. Christianity was by no means the religion only of slaves and of simple folk. Rather, the third century was an age of surprising Christians, of whom the emperor Constantine was only the last." ${ }^{, 49}$ Recent scholarship has called into question the understanding that early Christians were uneducated oppressed masses. Stark claims that the "new consensus" among historians is that Christianity was based in the middle and upper classes, and he contributes to the discussion by comparing early Christian communities to demographic studies of cults and sects in the U.S. ${ }^{50}$ Stark recognizes the objection that his approach is valid only in contemporary Western society, and he responds that such an objection (1) ignores the principles recognized by any "competent social scientist," and (2) ignores the evidence laid out in his entire book. ${ }^{51}$ Whether or not one agrees with the applicability of Stark's "scientific" methodology in regards to ancient North Africa, it establishes a theory of class with which to compare the data available to the historian. ${ }^{52}$

In the early period of African Christian history, the records suggest that both upper and lower class members of society existed within Christian communities. The Scillitan martyrs, although beheaded as if Roman citizens, are generally recognized as lower class members of society. ${ }^{53}$ In the Passio sanctarum

49 The Rise of Western Christendom: Triumph and Diversity, A.D. 200-1000, 2nd ed. (Oxford: Blackwell Publishing, 2003), 63-4.

50 The Rise, 31. Stark reflects earlier studies of Robin Scroggs, "The Sociological Interpretation of the New Testament: The Present State of Research," NTS 26 (1980): 164-78; and Robert M. Grant, Early Christianity and Society: Seven Studies, (San Francisco: Harper and Row, 1977), 11.

51 Ibid, 45.

52 The supposed "new consensus" has been sharply criticized. For Palestinian Christians of the 30s and 40s, see John Dominic Crossan, The Birth of Christianity: Discovering What Happened in the Years Immediately After the Execution of Jesus, (New York: HarperSanFranscisco, 1998), who uses anthropology of class, locating early Christians among the poor. For Pauline communities, see Meggitt, Paul, who engages anthropological theories, but prefers theories from the discipline of economics in helping to locate early Christians within the "general experience of deprivation and subsistence" (75).

Musurillo, The Acts, xxiii; Barnes, Tertullian, 63. 